\title{
Bioindicators of soil quality in coffee organic cultivation systems
}

\author{
Márcio Sampaio Pimentel(1), Helvécio De-Polli(2), Adriana Maria de Aquino( ${ }^{(3)}$, \\ Maria Elizabeth Fernandes Correia( ${ }^{(3)}$ and Janaina Ribeiro Costa Rouws ${ }^{(3)}$
}

\begin{abstract}
(1)Universidade Federal do Vale do São Francisco, Colegiado de Agronomia, Rodovia BR 407, Km 12, Lote 543, Projeto de Irrigação Senador Nilo Coelho, s/no, C1, CEP 56300-000 Petrolina, PE, Brazil. E-mail: marcio.pimentel@univasf.edu.br (2)Universidade Federal Rural do Rio de Janeiro, BR 465, Km 07, CEP 23890-000 Seropédica, RJ, Brazil. E-mail: depollih@gmail.com (3)Embrapa Agrobiologia, BR 465, Km 07, Caixa Postal 74.505, CEP 23851-970 Seropédica, RJ, Brazil. E-mail: adriana@cnpab.embrapa.br, ecorreia@cnpab.embrapa.br, janaina@cnpab.embrapa.br
\end{abstract}

Abstract - The objective of this work was to assess the effect of different coffee organic cultivation systems on chemical and biological soil characteristics, in different seasons of the year. The following systems were evaluated: coffee intercropped with one (CJ1), two (CJ2) or three (CJ3) pigeon pea (Cajanus cajan) alleys; coffee planted under full sun (CS); area planted with sweet pepper and snap bean in a conventional tillage system (AC); and secondary forest area (FFR). Row spacing in CJ1, CJ2, CJ3 and CS was 2.0x1.0, 2.8x1.0, $3.6 \times 1.0$, and $2.8 \times 1.0 \mathrm{~m}$, respectively. Soil samples were collected at $10-\mathrm{cm}$ depth, during the four seasons of the year. The results were subjected to analysis of variance, principal component analysis, and redundancy analysis. There was an increase in edaphic macrofauna, soil basal respiration, and microbial quotient in the summer. Total macrofauna density was greater in CJ2 followed by CJ3, CS, CJ1, AC and FFR; Coleoptera, Formicidae, and Isoptera were the most abundant groups. There are no significant differences among the areas for soil basal respiration, and the metabolic quotient is higher in CJ1, CJ3, and FFR. Microbial biomass carbon and the contents of $\mathrm{K}, \mathrm{pH}, \mathrm{Ca}+\mathrm{Mg}$, and $\mathrm{P}$ show greater values in $\mathrm{AC}$.

Index terms: Cajanus cajan, Coffea arabica, edaphic macrofauna, metabolic quotient, shading, soil microbial biomass.

\section{Bioindicadores de qualidade do solo em sistemas de cultivo orgânico de café}

Resumo - O objetivo deste trabalho foi avaliar o efeito de diferentes sistemas de cultivo orgânico do cafeeiro sobre as características químicas e biológicas do solo, em diferentes estações do ano. Foram avaliados os sistemas: consórcio do cafeeiro com uma (CJ1), duas (CJ2) ou três (CJ3) linhas de guandu (Cajanus cajan); plantio do café a pleno sol (CS); área de plantio convencional de pimentão e feijão-vagem (AC); e área de floresta secundária (AFS). O espaçamento entre linhas em CJ1, CJ2, CJ3 e CS foi de 2,0x1,0, 2,8x1,0, 3,6x1,0, e 2,8x1,0 m, respectivamente. O solo foi amostrado na profundidade de $10 \mathrm{~cm}$, nas quatro estações do ano. Os resultados foram submetidos à análise de variância, à análise de componentes principais e à análise de redundância. Houve aumento na macrofauna edáfica, na respiração basal do solo e no quociente microbiano, no verão. A densidade total da macrofauna foi maior em CJ2 seguidos por CJ3, CS, CJ1, AC e FFR; Coleoptera, Formicidae e Isoptera foram os grupos mais abundantes. Não há diferenças significativas entre as áreas quanto a respiração basal do solo, e o quociente metabólico é maior em CJ1, CJ3 e AFS. O carbono da biomassa microbiana e os teores de $\mathrm{K}, \mathrm{pH}, \mathrm{Ca}+\mathrm{Mg}$ e $\mathrm{P}$ são maiores em $\mathrm{AC}$.

Termos para indexação: Cajanus cajan, Coffea arabica, macrofauna edáfica, quociente metabólico, sombreamento, biomassa microbiana do solo.

\section{Introduction}

Coffee (Coffea arabica L.) crops are highly important for Brazilian agribusiness. In 2008, nearly two and a half million tons of coffee beans were harvested in Brazil, an increase of $16 \%$ in comparison to 2007 (Instituto Brasileiro de Geografia e Estatística, 2008). Coffee originally came from the deciduous forests in Ethiopia and Sudan, and has been associated with understory conditions. Latin American countries, such as Colombia, Costa Rica, Ecuador, and Guatemala, have been using shading as a technique for a more rational and conservationist use of the soil in coffee areas (Aquino et al., 2008a; Morais et al., 2009), in accordance with the precepts of organic agriculture sustainability.

The shading technique generates additional income for the farmer and maintains a balanced system by preserving biodiversity, soil, water resources, and carbon (Morais et al., 2009). The use of cover crops is relevant for maintaining and improving the chemical, physical, and biological characteristics of

Pesq. agropec. bras., Brasília, v.46, n.5, p.546-553, maio 2011 
the soil, allowing for the conservation of more balanced environments (Perin et al., 2003; Paciullo et al., 2007).

Rangel et al. (2008), while assessing the input of plant residues in coffee crops, observed a decrease in soil loss through erosion and an increase in soil organic carbon due to less soil tilling. Beer (1998) reported soil accumulation of up to $14 \mathrm{Mg} \mathrm{ha}^{-1}$ per year of residues originating from fallen leaves and pruned material, in dense coffee cropping. Aquino et al. (2008a), who evaluated earthworm populations in agroforestry systems with conventional and organic coffee crops, found lower earthworm density under full sun and that shading from Erythrina favored earthworm diversity. Therefore, conservationist practices, including better quality organic matter input, can result in greater earthworm abundance (Ortiz-Ceballos \& Fragoso, 2004).

Temperature, nutrient availability, and nitrogen $(\mathrm{N})$ supply are related to soil biological activity, as described by Cerri \& Volkoff (1988). The study of associations between biological and chemical attributes is important for understanding the best management practices in order to improve soil quality. Moreover, soil macrofauna can act as an indicator of environment-soil changes (Lavelle, 1997), and microbial properties allied to total organic carbon content can be used to assess the sustainability of agricultural production (Ferreira et al., 2010).

The objective of this work was to assess the effect of different coffee organic cultivation systems on chemical and biological soil characteristics, in different seasons of the year.

\section{Materials and Methods}

The experiment was carried out at the experimental area of Empresa de Pesquisa Agropecuária do Estado do Rio de Janeiro (Pesagro), located at municipality of Paty do Alferes, Rio de Janeiro, Brazil (22 46 'S and 43ㄴ' W, 507-m altitude), in a Typic Hapludox (Latossolo Vermelho-Amarelo). The region has annual mean rainfall of $1,185 \mathrm{~mm}$ and average temperature of $20.9^{\circ} \mathrm{C}$, with rainy season from November to April (Figure 1).

During the four seasons of 2002, edaphic macrofauna, microbial biomass carbon (MBC), soil basal respiration (SBR), metabolic quotient $\left(q \mathrm{CO}_{2}\right)$, microbial quotient ( $q \mathrm{Mic}$ ), and soil fertility were monitored in the following systems: two-year-old organic coffee crop (Catuaí Amarelo cultivar) containing one (CJ1), two (CJ2) or three alleys (CJ3) of pigeon pea (Cajanus cajan L.); coffee crop under full sun (CS); area planted with pepper (Capsicum annuum L.) and snap bean (Phaseolus vulgaris L.) in a conventional tillage system (AC); and secondary fragment of the Atlantic Rainforest (FFR), contiguous to the coffee crop.

The coffee crop was established in September 2000. Arandomized complete block design with four treatments and four replicates was used. The treatments with coffee plants had four combinations of row spacings: CJ1, 2.0x1.0 m; CJ2, 2.8x1.0 m; CJ3, 3.6x1.0; and CS, 2.8x1.0 $\mathrm{m}$. Pigeon pea row spacing was $1.0 \mathrm{x} 0.5,0.95 \times 0.5$, and $0.9 \times 0.5 \mathrm{~m}$ for CJ1, CJ2, and CJ3, respectively. The plots measured $90 \mathrm{~m}^{2}$ (CJ1), $126 \mathrm{~m}^{2}$ (CJ2 and CS), and $162 \mathrm{~m}^{2}$ (CJ3), and had 15 coffee plants per row. The areas AC and FFR measured, approximately, $400 \mathrm{~m}^{2}$ and 1 ha, respectively; both areas are located at Pesagro, at municipality of Paty do Alferes, Rio de Janeiro, Brazil.

The annual cropping area was fertilized with $1 \mathrm{~L}$ of chicken manure per hill and received daily irrigation and regular applications of the following agricultural chemicals: methamidophos (0,01 ppm), deltametrine $(0,001 \mathrm{ppm})$, and mancozeb (1 ppm) for vegetables (Brasil, 1985), besides lime sulphur and agrobio fertilizer.

At the coffee crop planting, in 1999, the soil was plowed, disked, and corrected with $80 \mathrm{~g}$ of dolomitic lime per hill. A fertilizer composed of $160 \mathrm{~g}$ of thermophosphate, $340 \mathrm{~g}$ of firewood ash, and $10 \mathrm{~L}$ of cattle manure was also applied at planting (Brasil, 1999), using $1 \mathrm{~L}$ per hill.

The soil attributes of the areas with coffee crop, conventional system, and forest fragment are present in Table 1. In order to evaluate the different treatments, soil samples were collected at a depth of $10 \mathrm{~cm}$ in March, June, September, and December 2002, representing

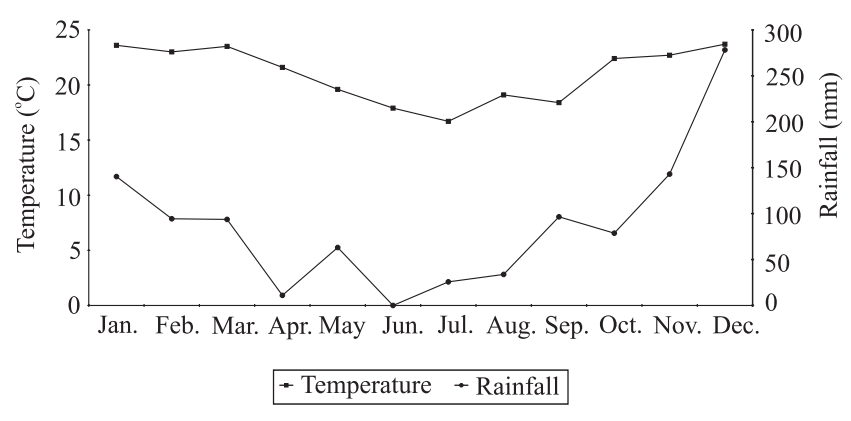

Figure 1. Monthly mean temperature and rainfall data collected at the experimental station of Avelar, in Paty do Alferes, RJ, Brazil, from March to December 2002. 
summer, autumn, winter, and spring, respectively. In the coffee crop treatments, six simple soil samples per plot were collected to make a composite sample for determination of $\mathrm{MBC}, \mathrm{SBR}, q \mathrm{CO}_{2}, q \mathrm{Mic}$, and fertility; four monoliths per plot were randomly collected for edaphic macrofauna evaluation. In the $\mathrm{AC}$ and FFR, ten simple samples were collected to make a composite sample per area for determination of $\mathrm{MBC}, \mathrm{SBR}, q \mathrm{CO}_{2}$, $q$ Mic, and fertility; eight monoliths per area were collected for edaphic macrofauna evaluation.

Microbial biomass carbon was assessed by the fumigation-extraction method (De-Polli \& Guerra, 2008), and SBR was evaluated according to Stotzky (1965). Metabolic quotient was calculated by the ratio between soil $\mathrm{C}$ respiration and microbial $\mathrm{C}$, in a time interval (Anderson \& Domsch, 1990), while $q$ Mic was obtained from the relationship between soil microbial C and soil organic C (Jenkinson \& Ladd, 1981).

Edaphic macrofauna sampling was done using the monolith method with a surface of $25 \times 25 \mathrm{~cm}$, recommended by Anderson \& Ingram (1993). Individual macrofauna with a length greater than $10 \mathrm{~mm}$ was manually removed and stored in bottles containing $70 \%$ alcohol for preservation until classification into large taxonomic groups and counting under a stereoscopic microscope. For analysis of the edaphic macrofauna, the term 'group' was used to refer to a family and a class or order, within the logic of taxonomic sufficiency. Communities were characterized in terms of total density (number of individuals per square meter) and median richness (number of groups per monolith).

Soil fertility ( $\mathrm{pH}, \mathrm{Al}, \mathrm{Ca}+\mathrm{Mg}, \mathrm{P}, \mathrm{K}$, and $\% \mathrm{C}$ ) was determined according to Silva (1999), and a kopeck ring was used to determine soil density. The soil was dried at $105^{\circ} \mathrm{C}$ for 48 hours, and weighted.

The data were subjected to analysis of variance using the Sisvar software (Ferreira, 2008), and means were compared by the Scott-Knott test, at 5\% probability. Total density, $q \mathrm{CO}_{2}$, and SBR were transformed using the $\log (\mathrm{x})$ function, and median richness with root $(\mathrm{x}+0.5)$ function. Significant between factors interactions were determined.

Principal component analysis (PCA) and redundancy analysis (RDA) were carried out using the program Canoco version 4.5 (Ter Braak \& Smilauer, 2002). Two PCA were performed for soil macrofauna and soil microbial attributes, in order to summarize the set of original chemical, physical, and biological variables, highly correlated, into a few principal components, which are linear combinations of noncorrelated original variables. Two RDA were carried out for soil macrofauna and soil microbial attributes, in order to verify the existence of the correlation between biological variables (density, richness of the edaphic macrofauna, MBC, $q \mathrm{Mic}, \mathrm{SBR}$, and $q \mathrm{CO}_{2}$ ) and explanatory variables, corresponding to soil physical and chemical attributes: apparent density (DAP), $\mathrm{pH}, \mathrm{Al}, \mathrm{Ca}+\mathrm{Mg}, \mathrm{P}, \mathrm{K}$, and $\% \mathrm{C}$.

The Monte Carlo permutation test was used to evaluate the significance of the relationship between the taxonomic units of the macrofauna and the explanatory variables. The eigenvalue obtained by the RDA is the squared sum of all the canonical values, representing the greatest degree of correlation of all the variables with the axis, which indicates the relative contribution of each axis for the explanation of the total data variance.

\section{Results and Discussion}

Edaphic macrofauna, $\mathrm{SBR}$, and $q \mathrm{CO}_{2}$ were positively correlated with summer, while MBC and $q$ Mic showed higher correlation with spring (Figures 2). Total macrofauna density was significantly greater in CJ2 followed by CJ3, CS, CJ1, AC and FFR (Table 2). For median richness, $\mathrm{CJ} 3$ and $\mathrm{CJ} 1$ were statistically the highest, followed by CJ2, CS, and FFR. The lowest median richness was found in $\mathrm{AC}$, probably due to the absence of living perennial mulch.

With PCA, it was possible to decompose variability into two groups of explanatory variables, i.e., seasons of the year and areas. The first two principal components

Table 1. Soil attributes under coffee crop, conventional system, and secondary forest.

\begin{tabular}{|c|c|c|c|c|c|c|c|c|c|c|c|c|c|}
\hline Soil area & Sand & $\begin{array}{r}\text { Silt } \\
-(\%)\end{array}$ & Clay & $\begin{array}{l}\text { Soil density } \\
\left(\mathrm{g} \mathrm{cm}^{-3}\right)\end{array}$ & $\mathrm{pH}$ & Al & $\mathrm{H}+\mathrm{Al}$ & $\begin{array}{l}\mathrm{Ca}+\mathrm{Mg} \\
\text { nolc dm }{ }^{-3}\end{array}$ & $\mathrm{~K}$ & CTC & $\begin{array}{c}\mathrm{P} \\
\left(\mathrm{mg} \mathrm{m}^{-3}\right)\end{array}$ & $\begin{array}{c}\mathrm{C} \\
--(\end{array}$ & N \\
\hline Coffee & 54.5 & 9.1 & 37.8 & 1.50 & 5.1 & 0.2 & 7.3 & 3.5 & 0.3 & 11.3 & 20.1 & 10.0 & 1.0 \\
\hline Conventional & 51.7 & 12.7 & 35.5 & 1.54 & 5.4 & 0.0 & 7.1 & 5.5 & 0.4 & 13.0 & 162.0 & 13.0 & 1.4 \\
\hline Forest & 57.6 & 9.5 & 32.9 & 1.40 & 5.0 & 0.8 & 8.7 & 2.8 & 0.2 & 12.5 & 7.8 & 14.0 & 1.6 \\
\hline
\end{tabular}


were responsible for $70.4 \%$ of the total variance in the original data, while Y1 and Y2 explained 41.7 and $28.7 \%$, respectively. Among the seasons, summer showed greater density for most of the groups, and strong correlation for Formicidae (ants) and Isoptera (termites). Formicidae and Isoptera were present in greater density in CJ2 and in $\mathrm{CJ} 3$, respectively, with correlation above 0.7 , which was the limit value used to indicate strong correlation. For $\mathrm{Y} 1$, the areas evaluated were ordered as follows: CJ3, CJ2, CJ1, CS, FFR, and AC. For Y2, the correlations between the fauna variables and the second axis were lower than 0.7 , indicating a smaller contribution of each variable to the axis, which did not allow an increase of information in the explanation by Y1.

CJ1 and CS are close to the center of Figure 2 A, while the other evaluated areas are distinct in terms of edaphic macrofauna. CJ2 and CJ3 showed greater soil fauna, due to the more effective presence of the herbaceous and shrub layer, which increases food availability for edaphic macrofauna (Souto et al., 2008). The opposite was observed for AC, which had the lowest values of edaphic macrofauna.

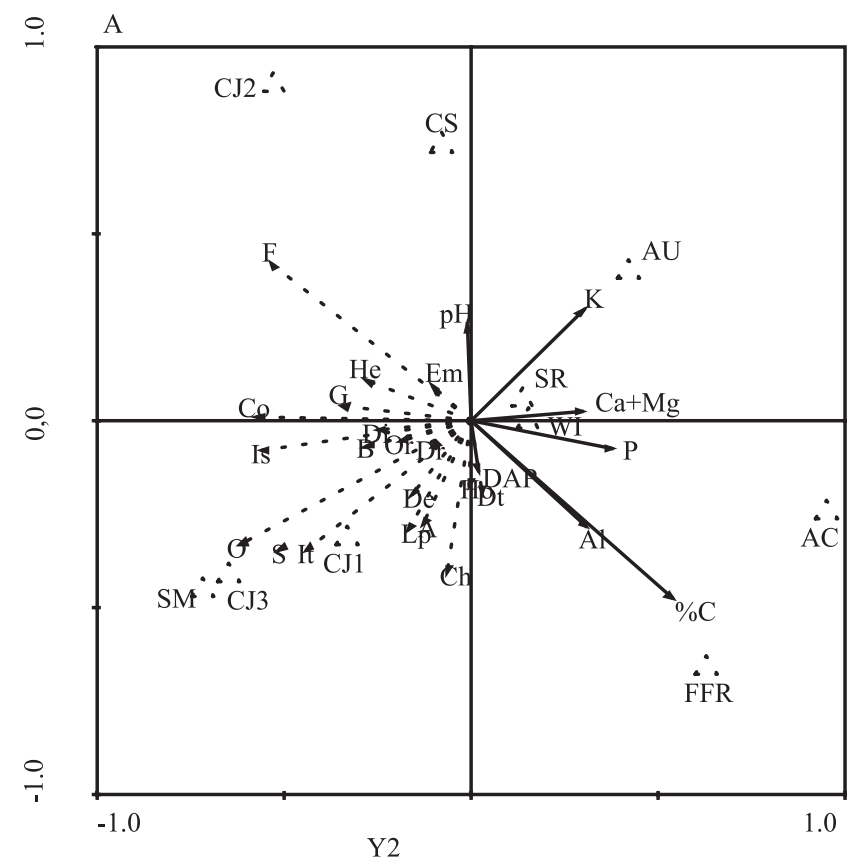

These results are similar to those found by Silva et al. (2006), while evaluating the following land use systems: conventional, no-tillage, crop-livestock integration, continuous pasture, and native vegetation. The authors observed that the no-tillage system showed the greatest diversity of groups. Santos et al. (2008), who assessed edaphic macrofauna under a no-tillage system, reported that the use of Crotalaria juncea L. favored macrofauna density. Silva et al. (2007) observed that using cover crops in a rotation system also favored macrofauna community. However, Aquino et al. (2008b), when evaluating edaphic macrofauna in a no-tillage system in the Brazilian Cerrado (tropical savanna), verified greater density and richness in the forest fragment soil.

According to Lavelle \& Spain (2001), there is an association between termites and organic material with high $\mathrm{C} / \mathrm{N}$ ratio. Pigeon pea, an arboreal plant rich in $\mathrm{C}$, may have contributed to the higher number of termites in CJ3, i.e., in environments in which there was a greater input of ligneous material through green manure. Lima et al. (2007) found similar results for ants and termites,

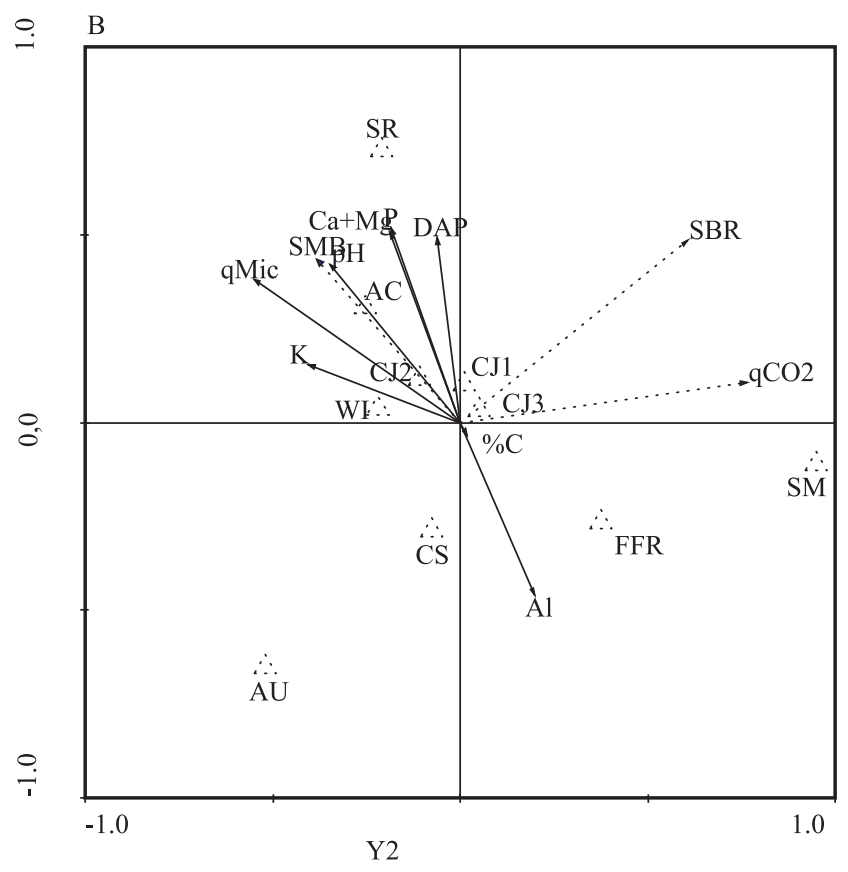

Figure 2. Principal component analysis of: A, edaphic macrofauna groups; and B, microbial biomass carbon (MBC), soil basal respiration (SBR), metabolic quotient $\left(q \mathrm{CO}_{2}\right)$, and microbial quotient $(q \mathrm{Mic})$, in the summer (SM), autumn $(\mathrm{AU})$, winter (WI), and spring (SR) for coffee crop with one (CJ1), two (CJ2) or three (CJ3) alleys of pigeon pea; coffee crop under full sun (CS); annual crop soil (AC); and secondary forest fragment soil (FFR). A, Araneae; B, Blattodea; Ch, Chilopoda; Co, Coleoptera; De, Dermaptera; Di, Diplopoda; Dr, Diplura; Dt, Diptera; En, Enchytraidae; F, Formicidae; G, Gastropoda; He, Heteroptera; Ho, Homoptera; Is, Isopoda; It, Isoptera; Lp, Lepidoptera; O, Oligochaeta; Or, Orthoptera; S, Symphyla. 
while evaluating soil macrofauna in an organic coffee management.

Huerta (2005), who studied the effect of the cover crop type on soil macrofauna, concluded that earthworm growth and reproduction rates increase with velvetbean and corn. Kitamura et al. (2008) observed an association of Coleoptera recovering areas, such as CJ2 and CJ3.

The area with coffee under full sun had low total density and median richness, as reported by Aquino et al. (2008a), who compared coffee crops under full sun and shaded crops with arboreal species. The presence or absence of living perennial mulch regulated the edaphic macrofauna, as demonstrated by Lima et al. (2010), when comparing soil macrofauna and chemical attributes to different systems. According to the authors, agroforestry management stimulated the occurrence of "ecosystem engineers" and promoted better soil chemical conditions. In the present study, AC showed detachment from the edaphic macrofauna (Figure 2A). Although the values of organic carbon for AC and FFR were close (13 and $14 \mathrm{~g} \mathrm{~kg}^{-1}$, respectively), the conditions provided by this cropping model were not favorable to the edaphic macrofauna, possibly due to the planting system using $\mathrm{N}$ fertilization, agricultural implements, soil tillage, and absence of plant cover (Tanck et al., 2000), which made AC soil biologically different from the others analyzed.

For soil microbiological data, the percentage of cumulative explanation up to the second principal component was $94.6 \%$, with Y1 and Y2 components explaining 64.3 and $30.3 \%$, respectively. Summer

Table 2. Total density (individuals per square meter), median richness, microbial biomass carbon $\left(\mathrm{mg} \mathrm{kg}^{-1}\right.$ of C), microbial quotient [Cmic (mg)/100 Corg (mg)], soil basal respiration $\left(\mathrm{mg} \mathrm{kg}^{-1} \mathrm{ha}^{-1}\right)$, and metabolic quotient $\left(\mathrm{mg} \mathrm{g}^{-1} \mathrm{~h}^{-1}\right)$ for coffee crop soil with one (CJ1), two (CJ2) or three (CJ3) alleys of pigeon pea; coffee crop under full sun (CS); conventional system (AC); and secondary forest fragment $(\mathrm{FFR})^{(1)}$.

\begin{tabular}{lrrrrrr}
\hline Atribute & \multicolumn{1}{c}{ CJ1 } & \multicolumn{1}{c}{ CJ2 } & \multicolumn{1}{c}{ CJ3 } & \multicolumn{1}{c}{ CS } & \multicolumn{1}{c}{ AC } & \multicolumn{1}{c}{ FFR } \\
\hline Density & $547.50 \mathrm{a}$ & $1,291.50 \mathrm{a}$ & $733.50 \mathrm{a}$ & $590.50 \mathrm{a}$ & $116.30 \mathrm{c}$ & $200.62 \mathrm{~b}$ \\
Richness & $4.22 \mathrm{a}$ & $3.56 \mathrm{~b}$ & $4.97 \mathrm{a}$ & $3.19 \mathrm{~b}$ & $1.08 \mathrm{~d}$ & $2.69 \mathrm{c}$ \\
$\mathrm{MBC}$ & $126.70 \mathrm{~b}$ & $132.10 \mathrm{~b}$ & $125.00 \mathrm{~b}$ & $111.10 \mathrm{~b}$ & $179.70 \mathrm{a}$ & $121.00 \mathrm{~b}$ \\
$q \mathrm{Mic}$ & $1.11 \mathrm{a}$ & $1.13 \mathrm{a}$ & $1.08 \mathrm{a}$ & $1.07 \mathrm{a}$ & $1.28 \mathrm{a}$ & $0.86 \mathrm{a}$ \\
$\mathrm{SBR}$ & $1.48 \mathrm{a}$ & $1.59 \mathrm{a}$ & $1.60 \mathrm{a}$ & $1.09 \mathrm{a}$ & $1.63 \mathrm{a}$ & $1.55 \mathrm{a}$ \\
$q \mathrm{CO}_{2}$ & $18.59 \mathrm{a}$ & $11.78 \mathrm{~b}$ & $15.40 \mathrm{a}$ & $11.53 \mathrm{~b}$ & $8.59 \mathrm{~b}$ & $15.31 \mathrm{a}$ \\
\hline
\end{tabular}

${ }^{(1)}$ Means followed by equal letters, on the same line, do not differ by the Scott-Knott test, at 5\% probability. MBC, microbial biomass carbon; $q \mathrm{Mic}$, microbial quotient; SBR, soil basal respiration; $q \mathrm{CO}_{2}$, metabolic quotient. showed differentiated behavior in comparison to spring, autumn, and winter (Figure $2 \mathrm{~B}$ ).

Weather was also an important factor that influenced the performance of microbial attributes. In the summer, rain and temperature influenced soil microorganism activity. For $\mathrm{Y} 1, q \mathrm{CO}_{2}$ and SBR increased and were positively correlated, showing strong (0.87) and medium correlation $(0.59)$ with summer, respectively. $\mathrm{Y} 2$ positively affected $q \mathrm{CO}_{2}(0.89)$.

The variables $q \mathrm{Mic}$ and $\mathrm{MBC}$ showed correlation coefficients for $\mathrm{Y} 1$ of -0.87 and -0.81 , respectively. Microbial biomass carbon and $q$ Mic were negatively correlated with SBR and $q \mathrm{CO}_{2}$, which indicates an inverse response, a result already found in other studies (Pimentel et al., 2006). During the spring, with approximately $300 \mathrm{~mm}$ of rainfall (Figure 1), $q$ Mic and $\mathrm{MBC}$ reached the highest values, indicating that, besides soil management, environmental conditions were more favorable to these attributes.

Weather influence on soil respiration was also observed by Balota et al. (1998), who reported greater values of SBR in a no-tillage system, during the summer. Soil basal respiration values were lower in autumn and winter, when the temperatures were the lowest, which confirms the correlation between SBR and environmental temperature.

The conventional system area showed significantly greater values for $\mathrm{MBC}$ and $q \mathrm{Mic}$ (Table 2). The secondary forest favored $q \mathrm{CO}_{2}$ and SBR (Figure 2B). No significant differences were observed for SBR among the areas by univariate analysis, while $q \mathrm{CO}_{2}$ was significantly greater in $\mathrm{CJ} 1, \mathrm{CJ} 3$, and FFR. These results differ from those of Moreira \& Malavolta (2004), while evaluating soil carbon and MBC dynamics. The authors observed that the rotation forestry-pasture-cupuaçu significantly reduced both attributes.

Redundancy analyses showed significance by the Monte Carlo permutation test $(\mathrm{p}=0.002,499$ permutations), which indicates that there is a correlation between biological variables and soil chemical attributes (Figure 3). The chemical attributes explained 42.8 and $51.1 \%$ of the variability in the edaphic macrofauna and microbiological data, respectively; 55 and $68.5 \%$ were explained on the first axis (Z1) and 27.5 and $28.4 \%$ on the second axis (Z2) (Table 3 and Figure 3).

In this study, organic carbon influenced the variability of the edaphic macrofauna, and $\mathrm{AC}$ and FFR soils were associated with elevated C. Greater C 

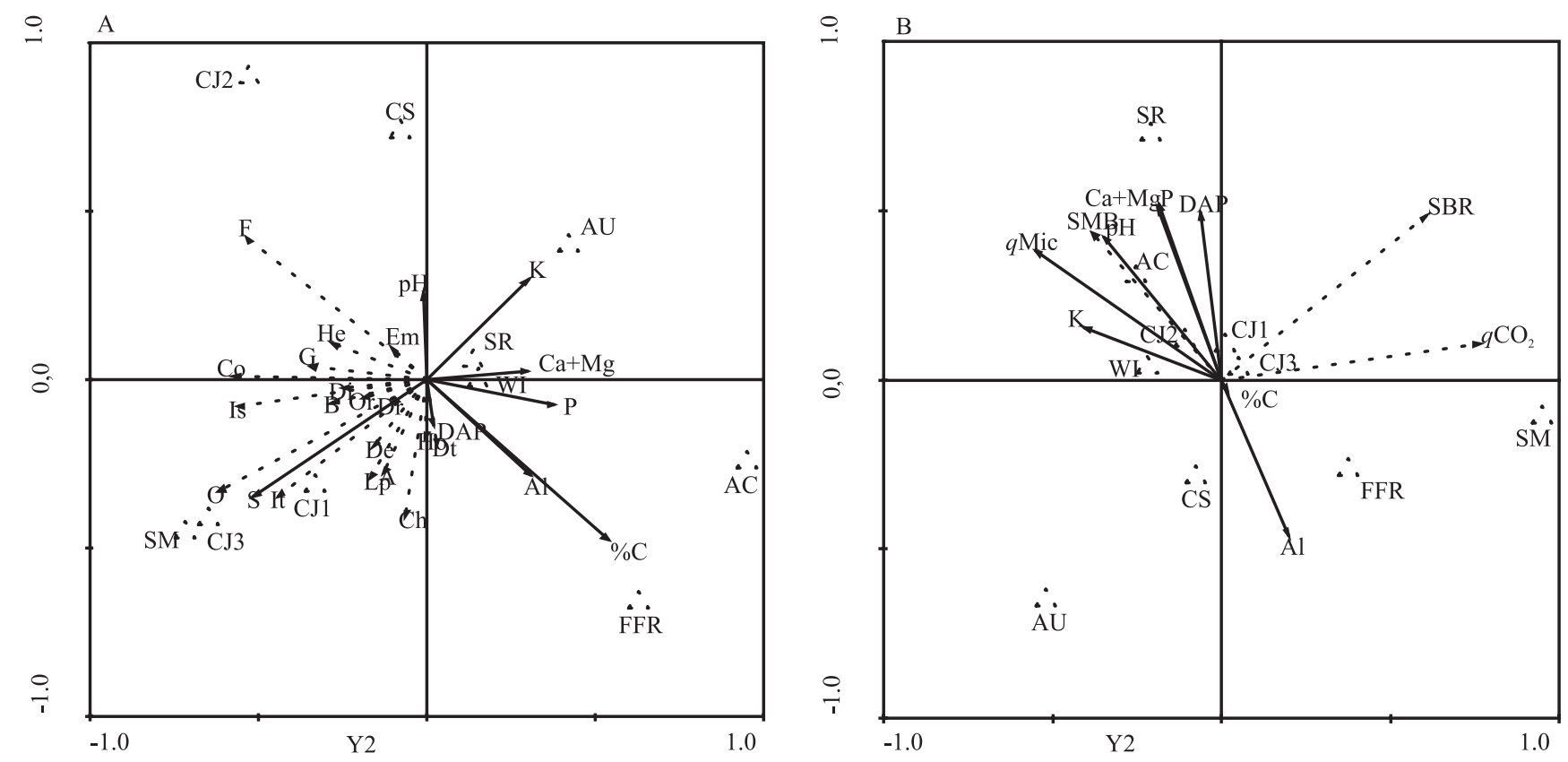

Figure 3. Redundancy analysis of: A, the edaphic macrofauna groups, organic carbon ( $\% \mathrm{C}), \mathrm{Al}, \mathrm{K}, \mathrm{P}, \mathrm{Ca}+\mathrm{Mg}, \mathrm{pH}$, and $\mathrm{DAP}$; and $\mathrm{B}$, soil microbial biomass $(\mathrm{SMB})$, soil basal respiration $(\mathrm{SBR})$, metabolic quotient $\left(q \mathrm{CO}_{2}\right)$, microbial quotient $(q \mathrm{Mic})$, $\% \mathrm{C}, \mathrm{Al}, \mathrm{K}, \mathrm{P}, \mathrm{Ca}+\mathrm{Mg}, \mathrm{pH}$, and Dap, in the summer (SM), autumn (AU), winter (WI), and spring (SR) for coffee crop with one (CJ1), two (CJ2) or three (CJ3) alleys of pigeon pea; coffee crop under full sun (CS); annual crop soil (AC); and secondary forest fragment soil (FFR). A, Araneae; B, Blattodea; Ch, Chilopoda; Co, Coleoptera; De, Dermaptera; Di, Diplopoda; Dt, Diptera; En, Enchytraeidae; F, Formicidae; G, Gastropoda; He, Heteroptera; Ho, Homoptera; Hy, Hymenoptera; Is, Isopoda; It, Isoptera; Lp, Lepidoptera; O, Oligochaeta; Or, Orthoptera; S, Symphyla.

Table 3. Redundancy analysis (RDA) between biological variables, considered dependent by RDA, and chemical attributes, considered independent.

\begin{tabular}{|c|c|c|c|c|c|c|}
\hline \multirow[t]{2}{*}{ RDA statistics } & \multicolumn{3}{|c|}{ Fauna vs. chemical } & \multicolumn{3}{|c|}{ Microbiological vs. chemical } \\
\hline & $1^{\text {st }}$ Axis & $2^{\text {nd }} A x i s$ & $3^{\text {rd }}$ Axis & $1^{\text {st }}$ Axis & $2^{\text {nd }}$ Axis & $3^{\text {rd }}$ Axis \\
\hline Eigenvalue & 0.236 & 0.118 & 0.023 & 0.350 & 0.145 & 0.011 \\
\hline \multirow[t]{2}{*}{ Correlation } & 0.780 & 0.670 & 0.690 & 0.750 & 0.670 & 0.670 \\
\hline & \multicolumn{6}{|c|}{ Cumulative explained variation (\%) } \\
\hline Dependent variables & 23.6 & 35.3 & 37.7 & 35.0 & 49.5 & 50.6 \\
\hline Dependent and independent variables & 55.0 & 82.5 & 88.0 & 68.5 & 96.9 & 99.1 \\
\hline
\end{tabular}

tends not to favor the density of Coleoptera, Formicidae, and Isopoda (Figure $3 \mathrm{~A}$ ).

Potassium content had greater influence on the variability of biological data, and $\mathrm{C}$ was not related to the biological variables analyzed (Figure $3 \mathrm{~B}$ ). Potassium content was positively correlated with $q$ Mic and $\mathrm{MBC}$, which were proportionally correlated with $\mathrm{pH}, \mathrm{Ca}+\mathrm{Mg}, \mathrm{P}$, and DAP, and inversely correlated with $\mathrm{Al}$ content (Z2).

Within the treatments analyzed, AC had the greatest $\mathrm{MBC}$ and the highest content of $\mathrm{K}, \mathrm{pH}, \mathrm{Ca}+\mathrm{Mg}$, and $\mathrm{P}$, which was probably motivated by fertilization, liming, and irrigation, which provided favorable conditions for microbial biomass (Table 2 and Figure 3 B). Fertilization and liming, located to the left of Figure $3 \mathrm{~B}$, may have favored soil microbial biomass, while $\mathrm{Al}$ content and $\mathrm{C}$ had strong correlation with FFR. In the spring, rainfall and $\mathrm{MBC}$ showed the highest values.

High levels of $\mathrm{Al}$ in forest soil has been reported in other studies (Souza et al., 2004; Longo et al., 2005). This could be attributed to FFR conditions, where there is no fertilization or liming to correct Al levels, and no soil disturbance, which allows the maintenance of the original vegetation and, consequently, carbon conservation. 


\section{Conclusions}

1. Edaphic macrofauna, soil basal respiration, and microbial quotient are positively correlated with summer.

2. Total macrofauna density is significantly greater in coffee crops, mainly with two or three alleys of pigeon pea, in which Coleoptera, Formicidae, and Isoptera are the most abundant groups.

3. There are no significant differences among the areas for soil basal respiration, and the metabolic quotient is greater in the coffee crop with one or three alleys of pigeon pea and in the secondary forest fragment.

4. Microbial carbon biomass shows greater values in the conventional area and the highest content of $\mathrm{K}$, $\mathrm{pH}, \mathrm{Ca}+\mathrm{Mg}$, and $\mathrm{P}$.

\section{Acknowledgements}

To Conselho Nacional de Desenvolvimento Científico e Tecnológico and to Fundação de Amparo à Pesquisa do Estado do Rio de Janeiro, for financial support; and to Embrapa Agrobiologia and Universidade Federal Rural do Rio de Janeiro, for structural support.

\section{References}

ANDERSON, J.M.; INGRAM, J.S.I. Tropical soil biology and fertility: a handbook of methods. $2^{\text {nd }}$ ed. Wallingford: CABI, 1993. 240p.

ANDERSON, T.H.; DOMSCH, K.H. Application of eco-physiological quotients $\left(q \mathrm{CO}_{2}\right.$ and $\left.q \mathrm{D}\right)$ on microbial biomasses from soils of different cropping histories. Soil Biology and Biochemistry, v.22, p.251-255, 1990.

AQUINO, A.M. de; MELOVIRGÍNIO FILHO, E. de; RICCI, M. dos S.F.; CASANOVES, F. Populações de minhocas em sistemas agroflorestais com café convencional e orgânico. Ciência e Agrotecnologia, v.32, p.1184-1188, 2008a.

AQUINO, A.M. de; SILVA, R.F. da; MERCANTE, F.M.; CORREIA, M.E.F.; GUIMARÃES, M. de F.; LAVELLE, P. Invertebrate soil macrofauna under different ground cover plants in the no-till system in the Cerrado. European Journal of Soil Biology, v.44, p.191-197, 2008b.

BALOTA, E.L.; COLOZZI-FILHO, A.; ANDRADE, D.S.; HUNGRIA, M. Biomassa microbiana e sua atividade em solos sob diferentes sistemas de preparo e sucessão de culturas. Revista Brasileira de Ciência do Solo, v.22, p.641-649, 1998.

BEER, J. Litter production and nutrient cycling in coffee (Coffea arabica) or cacao (Theobroma cacao) plantations with shade trees. Agroforest System, v.7, p.103-114, 1998.
BRASIL. Ministério da Agricultura e do Abastecimento. Instrução normativa $\mathrm{n}^{-}$7, de 17 de maio de 1999 . Dispõe sobre normas para a produção de produtos orgânicos vegetais e animais. Diário Oficial [da] República Federativa do Brasil, 19 maio 1999. Seção 1, p.11.

BRASIL. Anvisa. Portaria no ${ }^{-10}$, de 8 de março de 1985. Atribui à Dinal a compilação da relação de substâncias com ação tóxica sobre animais ou plantas, cujo registro pode ser autorizado no Brasil, em atividades agropecuárias e em produtos domissanitários e determina outras providências. Diário Oficial [da] República Federativa do Brasil, 14 mar. 1985.

CERRI, C.C.; VOLKOFF, B. Matéria orgânica de três solos dos campos inundáveis da Ilha de Marajó (PA). Revista Brasileira de Ciência do Solo, v.12, p.93-100, 1988.

DE-POLLI, H.; GUERRA, J.G.M. Carbono, nitrogênio e fósforo da biomassa microbiana do solo. In: SANTOS, G. de A.; SILVA, L.S. da; CANELLAS, L.P.; CAMARGO, F. de O. (Ed.). Fundamentos da matéria orgânica do solo: ecossistemas tropicais e subtropicais. 2.ed. Porto Alegre: Metrópole, 2008. p.263-276.

FERREIRA, D.F. SISVAR: um programa para análises e ensino de estatística. Revista Symposium, v.6, p.36-41, 2008.

FERREIRA, E.P. de B.; SANTOS, H.P. dos; COSTA, J.R.; DE-POLLI, H.; RUMJANEK, N.G. Microbial soil quality indicators under different crop rotations and tillage management. Revista Ciência Agronômica, v.41, p.177-183, 2010.

HUERTA, E.; FRAGOSO, C.; BAROIS, I.; LAVELlE, P. Enhancement of growth and reproduction of the tropical earthworm Polypheretima elongata (Megascolecidae) by addition of Zea mays and Mucuna pruriens var. utilis litter to the soil. European Journal of Soil Biology, v.41, p.45-53, 2005.

INSTITUTO BRASILEIRO DE GEOGRAFIA E ESTATÍSTICA. Levantamento sistemático da produção agrícola. 2008. Available in: <http://www.ibge.gov.br/home/presidencia/noticias/ noticia visualiza.php?id noticia $=1068 \&$ id pagina $=1>$. Accessed on: 19 May 2010.

JENKINSON, D.S.; LADD, J.N. Microbial biomass in soil: measurement and turnover. In: PAUL, E.A.; LADD, J.N. (Ed.). Soil biochemistry. New York: Marcel Dekker, 1981. p.415-471.

KITAMURA, A.E.; ALVES, M.C.; SUZUKI, L.G.A.S.; GONZALEZ, A.P. Recuperação de um solo degradado com a aplicação de adubos verdes e lodo de esgoto. Revista Brasileira de Ciência do Solo, v.32, p.405-416, 2008.

LAVELLE, P. Soil function in a changing world: the role of invertebrate ecosystem engineers. European Journal of Soil Biology, v.33, p.159-193, 1997.

LAVELLE, P.; SPAIN, A.V. Soil ecology. Dordrecht: Kluwer Academic, 2001. 654p.

LIMA, H.V. de; OLIVEIRA, T.S. de; OLIVEIRA, M.M. de; MENDONÇA, E. de S.; LIMA, P.J.B.F. Indicadores de qualidade do solo em sistemas de cultivo orgânico e convencional no semi-árido cearense. Revista Brasileira de Ciência do Solo, v.31, p.1085-1098, 2007.

LIMA, S.S. de; AQUINO, A.M. de; LEITE, L.F.C.; VELÁSQUEZ, E.; LAVELLE, P. Relação entre macrofauna edáfica e atributos 
químicos do solo em diferentes agroecossistemas. Pesquisa Agropecuária Brasileira, v.45, p.322-331, 2010.

LONGO, R.M.; RIBEIRO, A.Í.; MELO, W.J. de. Caracterização física e química de áreas mineradas pela extração de cassiterita. Bragantia, v.64, p.101-107, 2005.

MORAIS, H.; CARAMORI, P.H.; KOGUISHI, M.S.; GOMES, J.C.; RIBEIRO, A.M. de A. Sombreamento de cafeeiros durante o desenvolvimento das gemas florais e seus efeitos sobre a frutificação e produção. Ciência Rural, v.39, p.400-406, 2009.

MOREIRA, A.; MALAVOLTA, E. Dinâmica da matéria orgânica e da biomassa microbiana em solo submetido a diferentes sistemas de manejo na Amazônia Ocidental. Pesquisa Agropecuária Brasileira, v.39, p.1103-1110, 2004.

ORTIZ-CEBALLOS, A.I.; FRAGOSO, C. Earthworm populations under tropical maize cultivation: the effect of mulching with velvetbean. Biology and Fertility of Soils, v.39, p.438-445, 2004.

PACIULLO, D.S.C.; CARVALHO, C.A.B. de; AROEIRA, L.J.M.; MORENZ, M.J.F.; LOPES, F.C.F.; ROSSIELLO, R.O.P. Morfofisiologia e valor nutritivo do capim-braquiária sob sombreamento natural e a sol pleno. Pesquisa Agropecuária Brasileira, v.42, p.573-579, 2007.

PERIN, A.; GUERRA, J.G.M.; TEIXEIRA, M.G. Cobertura do solo e acumulação de nutrientes pelo amendoim forrageiro. Pesquisa Agropecuária Brasileira, v.38, p.791-796, 2003.

PIMENTEL, M.S.; AQUINO, A.M. de; CORREIA, M.E.F.; COSTA, J.R.; RICCI, M. dos S.F.; DE-POLLI, H. Atributos biológicos do solo sob manejo orgânico de cafeeiro, pastagem e floresta em região do Médio Paraíba Fluminense-RJ. Coffee Science, v.1, p.85-93, 2006.

RANGEL， O.J.P.; SILVA， C.A.; GUIMARÃES， P.T.G.; MELO, L.C.A.; OLIVEIRA JUNIOR, A.C. de. Carbono orgânico e nitrogênio total do solo e suas relações com os espaçamentos de plantio de cafeeiro. Revista Brasileira de Ciência do Solo, v.32, p.2051-2059, 2008.
SANTOS, G.G.; SILVEIRA, P.M. da; MARCHÃO, R.L.; BECQUER, T.; BALBINO, L.C. Macrofauna edáfica associada a plantas de cobertura em plantio direto em um Latossolo Vermelho do Cerrado. Pesquisa Agropecuária Brasileira, v.43, p.115-122, 2008.

SILVA, F.C. da (Org.). Manual de análises químicas de solos, plantas e fertilizantes. Brasília: Embrapa Comunicação para Transferência de Tecnologia, 1999. 370p.

SILVA, R.F. da; AQUINO, A.M. de; MERCANTE, F.M.; GUIMARÃES, M. de F. Macrofauna invertebrada do solo sob diferentes sistemas de produção em Latossolo da Região do Cerrado. Pesquisa Agropecuária Brasileira, v.41, p.697-704, 2006.

SILVA, R.F. da; TOMAZI, M.; PEZARICO, C.R.; AQUINO, A.M. de; MERCANTE, F.M. Macrofauna invertebrada edáfica em cultivo de mandioca sob sistemas de cobertura do solo. Pesquisa Agropecuária Brasileira, v.42, p.865-871, 2007.

SOUTO, P.C.; SOUTO, J.S.; MIRANDA, J.R.P. de; SANTOS, R.V. dos; ALVES, A.R. Comunidade microbiana e mesofauna edáficas em solo sob caatinga no semi-árido da Paraíba. Revista Brasileira de Ciência do Solo, v.32, p.151-160, 2008.

SOUZA, Z.M.; LEITE, J.A.; BEUTLER, A.N. Comportamento de atributos físicos de um Latossolo Amarelo sob agroecossistemas do Amazonas. Engenharia Agrícola, v.24, p.654-662, 2004.

STOTZKY, G. Microbial respiration. In: BLACK, C.A.; EVANS, D.D.; WHITE, J.L.; ENSNUNGER, L.E.; CLARK, F.E.; DINAUER, R.C. (Ed.). Methods of soil analysis. Madison: American Society of Agronomy, 1965. pt.2, p.1550-1572. (ASA. Agronomy, 9).

TANCK, B.C.B.; SANTOS, H.R.; DIONÍSIO, J.A. Influência de diferentes sistemas de uso e manejo do solo sobre a flutuação populacional do Oligochaeta edáfico Amynthas spp. Revista Brasileira de Ciência do Solo, v.24, p.409-415, 2000.

TER BRAAK, C.J.F.; SMILAUER, P. Canoco for Windows. Version 4.5. Wageningen: Plant Research International, 2002.

Received on November 28, 2010 and accepted on April 4, 2011

Pesq. agropec. bras., Brasília, v.46, n.5, p.546-553, maio 2011 